\title{
Quantification of two isomeric flavones in rat colon tissue using reverse phase high performance liquid chromatography
}

\author{
Crystal L. Whitted', Victoria E. Palau', Ruben D. Torrenegra ${ }^{2}$, Oscar E. Rodriguez ${ }^{3}$ and Sam Harirforoosh ${ }^{1 *}$ (D)
}

\begin{abstract}
Background: Antineoplastic activity has been previously shown for two isomeric flavones, 5,7-dihydroxy-3,6,8trimethoxy flavone (flavone A) and 3,5-dihydroxy-6,7,8-trimethoxy flavone (flavone B), against colon cancer cell lines (Thomas et al. in PLOS ONE 7:e39806, 5). Here, we present modified methods for the extraction and quantification of flavones $A$ and $B$ in rat colon tissue after intravenous dosing via high performance liquid chromatography, from the originally described procedure for extraction and quantification in rat plasma (Whitted et al. in J Chromatogr B Analyt Technol Biomed Life Sci 1001:150-155, 7).

Results: Modifications included tissue homogenization (1 $\mathrm{g}$ tissue: $2 \mathrm{~mL}$ water), filtration of the supernatant with a PVDF membrane, and the use of only one calibration curve to determine the concentration of each flavone in colon tissue. Good separation was achieved and representative equations were linear with $r^{2} \geq 0.99$ for both flavones. Precision and accuracy for flavone A ranged from $0.88-24.03$ and 109-116\%. Precision and accuracy for flavone B ranged from 1.62-33.56 and 98-113\%. Concentrations of $1639 \pm 601 \mathrm{ng} / \mathrm{g}$ flavone A and $5975 \pm 2480 \mathrm{ng} / \mathrm{g}$ of flavone B were detected in rat colon tissue $6 \mathrm{~h}$ post dosing.
\end{abstract}

Conclusions: Modifications to the extraction methods for flavone A and flavone B from rat colon tissue had good separation, precision, and accuracy.

Keywords: 5,7-Dihydroxy-3,6,8-trimethoxy flavone, 3,5-Dihydroxy-6,7,8-trimethoxy flavone, HPLC, Colon, Flavonoids, Cancer

\section{Background}

Many flavonoids have been recognized for their antitumor properties [1-4]. It is known that these activities are greatly determined by their chemical structure which subsequently dictates their ability to interact with cellular molecules [1]. This differential effect has been observed with flavone isomers 5,7-dihydroxy-3,6,8-trimethoxy flavone (flavone A) and 3,5-dihydroxy-6,7,8-trimethoxy flavone (flavone B) [5]. Specifically, each isomer has been shown to target colon cancer cells with distinct phenotypical characteristics via different mechanisms of action

\footnotetext{
*Correspondence: harirfor@etsu.edu

${ }^{1}$ Department of Pharmaceutical Sciences, Gatton College of Pharmacy,

East Tennessee State University, Box 70594, Johnson City,

TN 37614-1708, USA

Full list of author information is available at the end of the article
}

[6]. However, it is unknown whether either of these flavones distribute to the colon after intravenous administration of these compounds. Modifications were made to methods developed for extracting and quantifying these flavones in rat plasma [7] using reverse phase high performance liquid chromatography (HPLC). The modifications included preparation of the sample by homogenization in water, filtration using a polyvinylidene fluoride (PVDF) membrane, and the creation of a single calibration curve to determine the concentration of either flavone in colon tissue.

These methods allowed for the detection of flavone A and flavone $\mathrm{B}$ in rat colon. Our data indicate that flavone $B$ was found in higher concentrations in the colon than flavone A, which may be the result of higher volume of 
distribution value of flavone $B$ [7] compared to that of flavone $\mathrm{A}$.

\section{Methods}

\section{Procedure to extract and purify flavones $A$ and $B$}

The compounds were obtained as described before [5]. Briefly, flavone A was purified from dried flowers of Gnaphalium elegans extracted with chloroform using a silica gel chromatography column. Flavone B was purified from leaves of Achyrocline bogotensis, using chloroform, followed by crystallizations in hexane. The physical and spectroscopic properties of these compounds allowed their proper identification.

\section{Stock solution and standards}

Stock solutions of flavone A at a concentration of $100 \mu \mathrm{g} /$ $\mathrm{mL}$, prepared as described previously [7], and $25 \mu \mathrm{g} / \mathrm{mL}$ celecoxib (Toronto Research Chemicals; Toronto, ON, CA) were prepared with acetonitrile/water/acetic acid/ triethylamine (60:40:0.2:0.05). Stock solutions of $100 \mu \mathrm{g} /$ $\mathrm{mL}$ of flavone $\mathrm{B}$, prepared as described previously [7], and $25 \mu \mathrm{g} / \mathrm{mL}$ diclofenac (MP Biomedicals, LLC; Solon, $\mathrm{OH})$ were prepared with acetonitrile/water/acetic acid/ trimethylamine (70:30:0.2:0.05). All stock solutions were stored protected from light at $4{ }^{\circ} \mathrm{C}$. HPLC grade acetonitrile, acetic acid, trimethylamine, and water were purchased from Fisher Scientific (Pittsburgh, PA). Flavone A or flavone B were mixed with polyethylene glycol 400 (Electron Microscopy Sciences; Hatfield, PA) for intravenous injection.

\section{Sample preparation}

Colon tissue was homogenized using a PowerGen 700 from Fisher Scientific (Pittsburgh, PA) in a 1:2 ratio with water $(1 \mathrm{mg} / 2 \mathrm{~mL})$. Serial concentrations for calibration curves (flavone A: $250-100,000 \mathrm{ng} / \mathrm{g}$ and flavone B: $1000-25,000 \mathrm{ng} / \mathrm{g}$ ) were prepared. Briefly, $100 \mu \mathrm{L}$ of blank homogenate was spiked with $100 \mu \mathrm{L}$ flavone, 100 $\mu \mathrm{L}$ internal standard ( $25 \mu \mathrm{g} / \mathrm{mL}$ celecoxib or diclofenac), and $200 \mu \mathrm{L}$ of organic solvent (acetonitrile). The samples were vortex mixed before being centrifuged for $15 \mathrm{~min}$ at $3000 \times g$. The supernatant was removed and filtered with a PDVF filter $(0.45 \mu \mathrm{m})$ into a clean tube and evaporated using a Labconco vacuum concentrator (Kansas City, MO). Mobile phase $(200 \mu \mathrm{L})$ was used to reconstitute the residue and $100 \mu \mathrm{L}$ of sample was injected into the HPLC column. Analysis was conducted in triplicate.

\section{HPLC conditions and quantitation}

HPLC assays were performed using a Shimadzu liquid chromatography system (Shimadzu Scientific Instruments Inc., Columbia, Maryland, USA) with an ACE C18 $(100 \times 4.6 \mathrm{~mm})$ (Aberdeen, Scotland) column. Mobile phases used for HPLC contained acetonitrile/water 60:40 (flavone A) and 70:30 (flavone B) with $0.2 \%$ acetic acid and $0.05 \%$ triethylamine. Detection wavelength was at $245 \mathrm{~nm}$ with a temperature of $30{ }^{\circ} \mathrm{C}$. Flow rate was $0.4 \mathrm{~mL} / \mathrm{min}$ with run times of 11 and $10 \mathrm{~min}$, respectively. LC solutions program was used to collect and analyze the data.

\section{Animals and drug administration}

The methods described here were used to determine the concentrations of flavone A or flavone B in colon tissue collected from male Sprague-Dawley rats (Charles River Laboratories, Raleigh, NC, USA) used in a previous study [7]. Briefly, flavones were mixed in polyethylene glycol 400 and were administered by intravenous injection to deliver a $20 \mathrm{mg} / \mathrm{kg}$ dose of flavone $\mathrm{A}(\mathrm{n}=6)$ or flavone $B(n=6)$. Animals were euthanized under anesthesia $6 \mathrm{~h}$ post dosing. Colon tissue was collected and flash frozen using dry ice and stored at $-80{ }^{\circ} \mathrm{C}$ until analyzed for the measurement of concentrations of flavones.

\section{Results}

Good separation was achieved (Figs. 1, 2) and the peak area ratios of flavone against internal standard were plotted in Excel to make the calibration curves (Fig. 3). Representative equation for flavone A concentrations $250-100,000 \mathrm{ng} / \mathrm{g}$ was $\mathrm{y}=2 \mathrm{E}-05 \mathrm{x}+0.0029$ and flavone $B$ concentrations $1000-25,000 \mathrm{ng} / \mathrm{g}$ was $\mathrm{y}=7 \mathrm{E}-05 \mathrm{x}+0.0531$ with $r^{2} \geq 0.99$. Three calibration curves were used to determine the precision (coefficient of variation- $\mathrm{CV}$ ) and accuracy of the methods. Data is presented as mean \pm standard deviation (Tables 1 , 2). Analysis yielded $1639 \pm 601 \mathrm{ng} / \mathrm{g}$ of flavone $\mathrm{A}$ and $5975 \pm 2480 \mathrm{ng} / \mathrm{g}$ of flavone B in colon tissue (Fig. 4).

\section{Conclusion}

Modifications to the methods developed for extraction and quantification of flavone A and flavone B from rat colon tissue yield good separation, precision, and accuracy. The distribution of both flavones to the colon suggests that they would be good candidates for in vivo antitumor studies for colon cancer. 


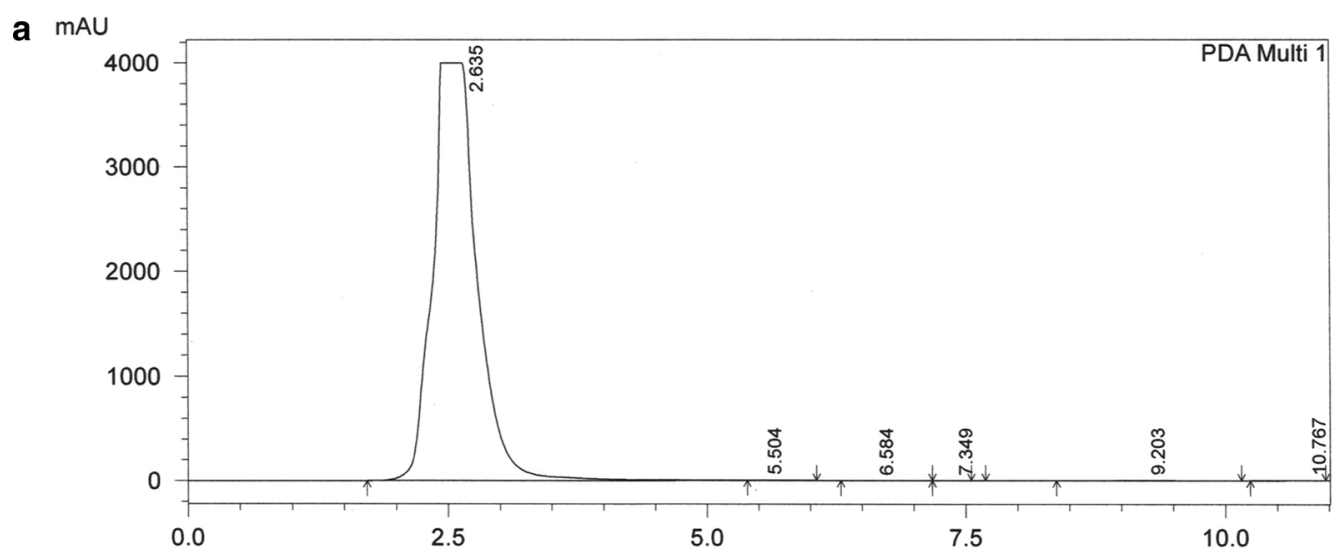

b $\mathrm{mAU}$

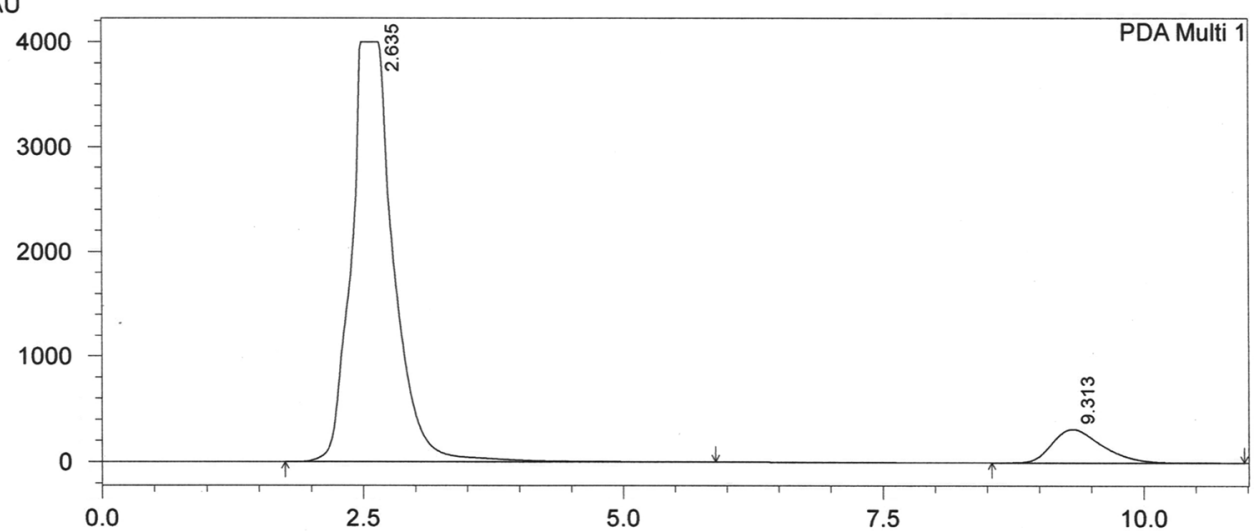

C $\mathrm{MAU}$

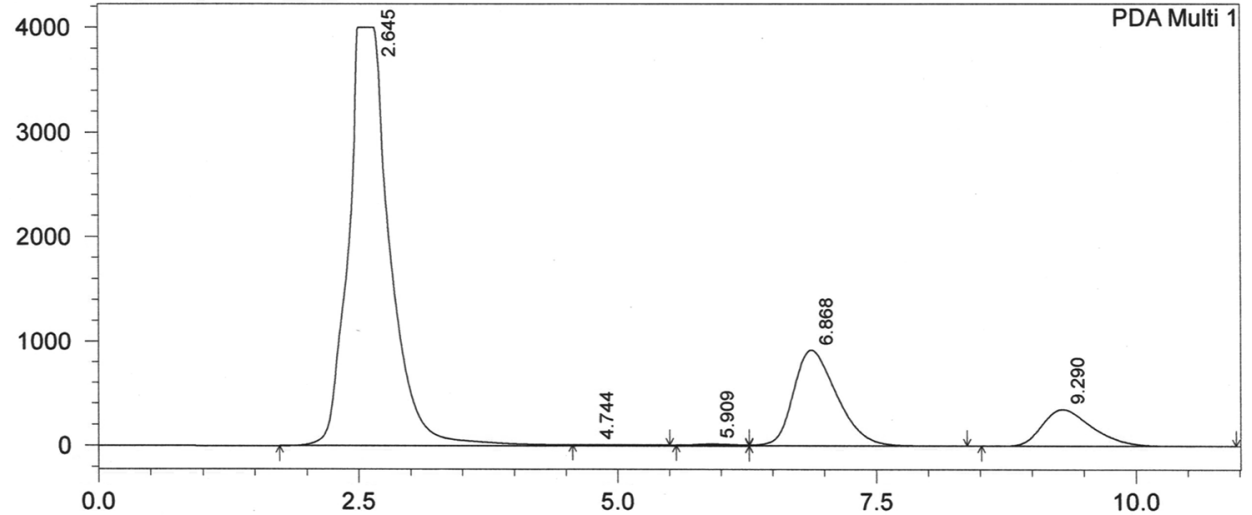

Fig. 1 Elution of flavone A from colon. HPLC chromatographs of a blank colon; b colon spiked with internal standard (celecoxib $25 \mu \mathrm{g} / \mathrm{mL}$ ); c colon spiked with flavone A $(100 \mu \mathrm{g} / \mathrm{mL})$ and internal standard 


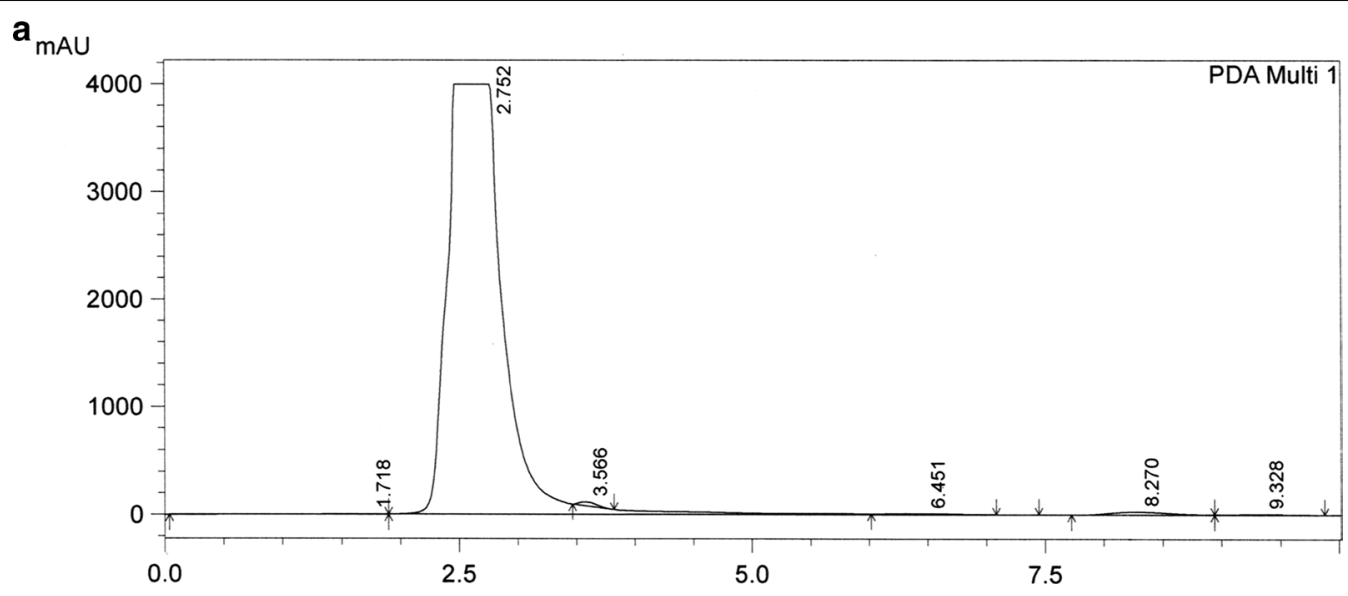

b $\mathrm{mAU}$

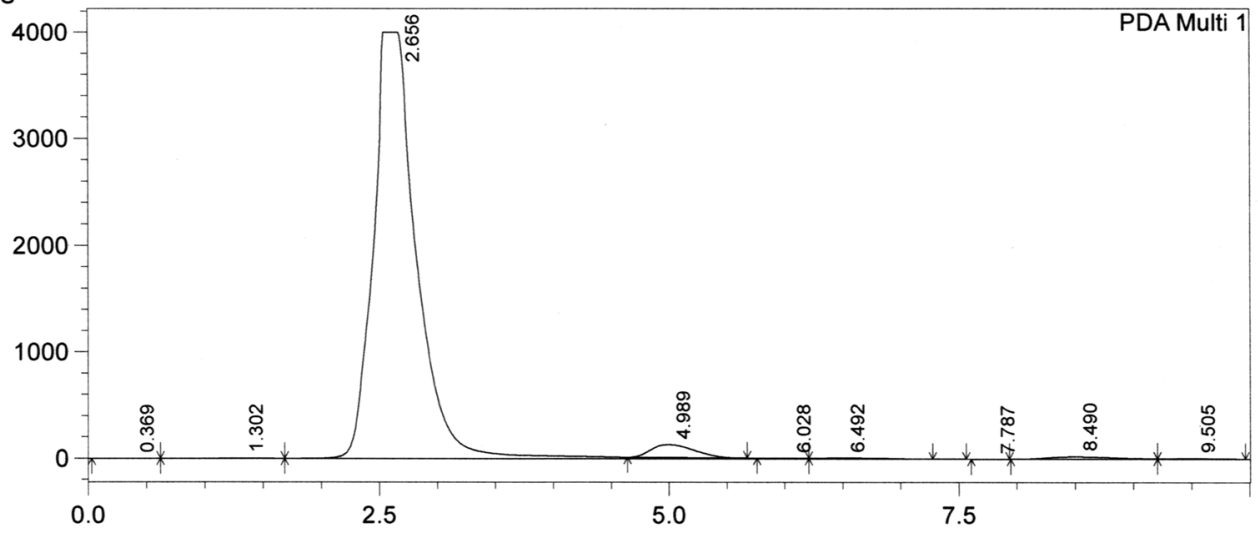

$\mathbf{C}_{\text {mAU }}$

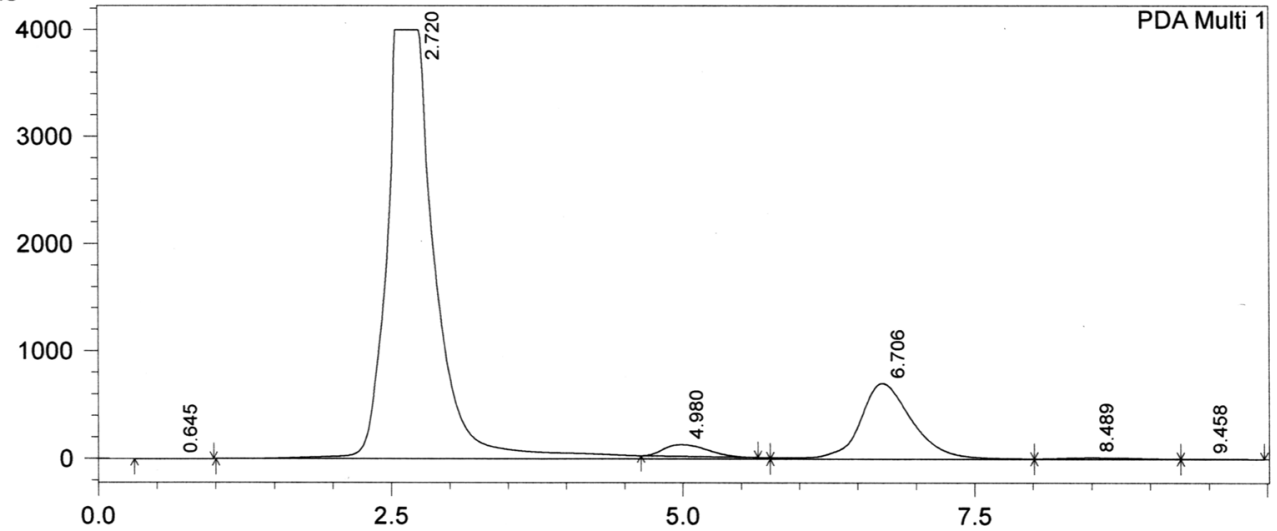

Fig. 2 Elution of flavone B from colon. HPLC chromatographs of a blank colon; b colon spiked with internal standard (diclofenac $25 \mu \mathrm{g} / \mathrm{mL}$ ); c colon spiked with flavone $B(100 \mu \mathrm{g} / \mathrm{mL})$ and internal standard 

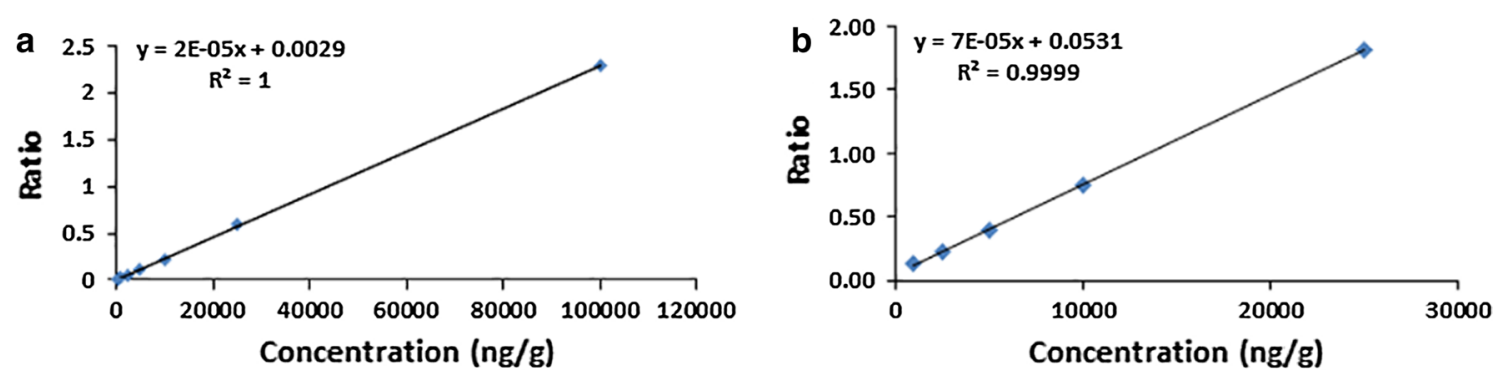

Fig. 3 Calibration curves were made by graphing the ratio of flavone/internal standard area under the curve extracted from colon tissue versus the known concentration of flavone. Representative calibration curves for $\mathbf{a}$ flavone $\mathrm{A}$ and $\mathbf{b}$ flavone $\mathrm{B}$ are presented

Table 1 Precision and accuracy for $250-100,000 \mathrm{ng} / \mathrm{g}$ flavone $A$ extracted from rat colon tissue

\begin{tabular}{lcccl}
\hline $\begin{array}{l}\text { Concentration } \\
\text { (ng/g) }\end{array}$ & Error (\%) & $\begin{array}{l}\text { Observed } \\
(\mathbf{n = 3})\end{array}$ & CV & Accuracy (\%) \\
\hline 100,000 & $13.88 \pm 2.14$ & $113,888 \pm 2138$ & 1.87 & 114 \\
25,000 & $16.32 \pm 1.06$ & $29,081 \pm 265$ & 0.91 & 116 \\
10,000 & $11.83 \pm 4.15$ & $11,182 \pm 415$ & 3.71 & 111 \\
5000 & $9.93 \pm 0.97$ & $5496 \pm 48$ & 0.88 & 109 \\
2500 & $13.92 \pm 4.87$ & $2848 \pm 121$ & 4.27 & 113 \\
1000 & $11.45 \pm 8.90$ & $1114 \pm 89$ & 7.98 & 111 \\
500 & $16.65 \pm 21.51$ & $558 \pm 129$ & 23.21 & 111 \\
250 & $21.02 \pm 19.30$ & $285 \pm 68$ & 24.03 & 113 \\
\hline
\end{tabular}

Table 2 Precision and accuracy for $1000-25,000 \mathrm{ng} / \mathrm{g}$ flavone $B$ extracted from rat colon tissue

\begin{tabular}{lclrl}
\hline $\begin{array}{l}\text { Concentration } \\
\text { (ng/g) }\end{array}$ & Error (\%) & $\begin{array}{l}\text { Observed } \\
(\mathbf{n = 3})\end{array}$ & CV & Accuracy (\%) \\
\hline 25,000 & $1.51 \pm 0.50$ & $25,204 \pm 410$ & 1.62 & 101 \\
10,000 & $2.89 \pm 0.52$ & $10,075 \pm 345$ & 3.43 & 101 \\
5000 & $3.69 \pm 3.42$ & $4934 \pm 271$ & 5.51 & 98 \\
2500 & $4.22 \pm 2.55$ & $2480 \pm 142$ & 5.73 & 99 \\
1000 & $25.18 \pm 27.00$ & $1128 \pm 378$ & 33.56 & 113 \\
\hline
\end{tabular}

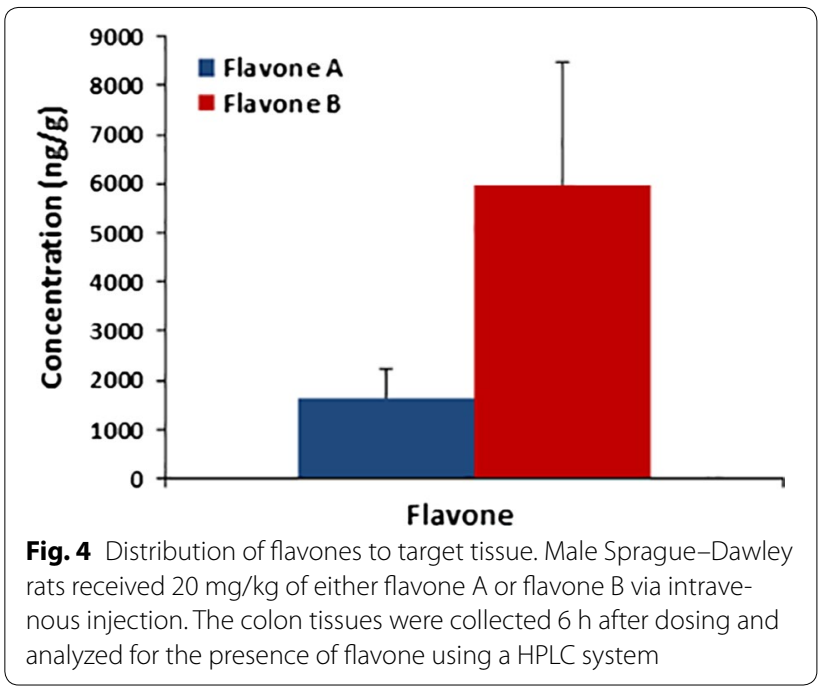

\section{Abbreviations}

Flavone A: 5,7-dihydroxy-3,6,8-trimethoxy flavone; Flavone B: 3,5-dihydroxy-6,7,8-trimethoxy flavone; HPLC: high performance liquid chromatography; PVDF: polyvinylidene fluoride.

\section{Authors' contributions}

SH designed the experiments, analyzed the data, and wrote the manuscript. CLW perfumed the experiments, analyzed the data, and wrote the manuscript. VEP analyzed the data and wrote the manuscript. RDT and OER extracted and purified flavones $A$ and $B$ and wrote the manuscript. All authors read and approved the final manuscript.

\section{Author details}

${ }^{1}$ Department of Pharmaceutical Sciences, Gatton College of Pharmacy, East Tennessee State University, Box 70594, Johnson City, TN 37614-1708, USA. ${ }^{2}$ Universidad de Ciencias Aplicadas y Ambientales, Bogotá, Colombia. ${ }^{3}$ Department of Environmental Engineering, Faculty of Engineering, Universidad El Bosque, Bogotá, Colombia.

\section{Acknowledgements}

Not applicable.

\section{Competing interests}

The authors declare that they have no competing interests.

\section{Availability of data and materials}

The dataset supporting the conclusions of this article are available upon request from the first author manuscript.

\section{Ethics approval and consent to participate}

The study protocol (P-131001) was approved by the East Tennessee State University Committee on Animal Care, and conducted in facilities accredited by AAALAC according to guidelines in the Public Health Service Guide for the Care and Use of Laboratory Animals.

\section{Funding}

This study was funded by a grant from the East Tennessee State University Research Development Committee Major Grants Program. The funding body had no role in the design of the study and collection, analysis, and interpretation of data and in writing the manuscript.

Received: 22 June 2016 Accepted: 20 December 2016

Published online: 07 January 2017

\section{References}

1. Lopez-Lazaro M. Flavonoids as anticancer agents: structureactivity relationship study. Curr Med Chem Anticancer Agents. 2002;2:691-714 
2. Kandaswami C, Lee LT, Lee PP, Hwang JJ, Ke FC, Huang YT, Lee MT. The antitumor activities of flavonoids. In Vivo. 2005;19:895-909.

3. Wang HK. The therapeutic potential of flavonoids. Expert Opin Investig Drugs. 2000;9:2103-19.

4. Kale A, Gawande S, Kotwal S. Cancer phytotherapeutics: role for flavonoids at the cellular level. Phytother Res. 2008;22:567-77.

5. Thomas CM, Wood RC 3rd, Wyatt JE, Pendleton MH, Torrenegra RD, Rodriguez OE, Harirforoosh S, Ballester M, Lightner J, Krishnan K, Ramsauer VP. Anti-neoplastic activity of two flavone isomers derived from Gnaphalium elegans and Achyrocline bogotensis. PLOS ONE. 2012;7:e39806.
6. LeJeune TM, Tsui HY, Parsons LB, Miller GE, Whitted C, Lynch KE, Ramsauer RE, Patel JU, Wyatt JE, Street DS, et al. Mechanism of action of two flavone isomers targeting cancer cells with varying cell differentiation status. PLOS ONE. 2015;10:e0142928.

7. Whitted CL, Palau VE, Torrenegra RD, Harirforoosh S. Development of reversed-phase high performance liquid chromatography methods for quantification of two isomeric flavones and the application of the methods to pharmacokinetic studies in rats. J Chromatogr B Analyt Technol Biomed Life Sci. 2015;1001:150-5.

\section{Submit your next manuscript to BioMed Central and we will help you at every step:}

- We accept pre-submission inquiries

- Our selector tool helps you to find the most relevant journal

- We provide round the clock customer support

- Convenient online submission

- Thorough peer review

- Inclusion in PubMed and all major indexing services

- Maximum visibility for your research

Submit your manuscript at www.biomedcentral com/submit 